Original Research Paper

\title{
Growth of Pepper Plant (Piper nigrum Linn.) After Application of Organic Fertilizer Leaves of Gamal (Gliricidia sepium (Jacq) Kunth.)
}

\author{
Iir Purwanto ${ }^{1}$, Zulfa Zakiah ${ }^{1 *}$, Riza Linda ${ }^{1}$ \\ ${ }^{1}$ Jurusan Biologi Fakultas MIPA, Universitas Tanjungpura, Pontianak, Indonesia
}

\author{
Article History \\ Received : August $15^{\text {th }}, 2021$ \\ Revised : August 30 $0^{\text {th }}, 2021$ \\ Accepted : September $15^{\text {th }}, 2021$ \\ Published : September 23 ${ }^{\text {th }}, 2021$ \\ *Corresponding Author: \\ Zulfa Zakiah, \\ Jurusan Biologi, Fakultas \\ Matematika dan Ilmu \\ Pengetahuan Alam, Universitas \\ Tanjungpura, Pontianak. \\ Email: zulfazakiah@gmail.com
}

\begin{abstract}
Pepper (Piper nigrum Linn.) is the most traded spice commodity among other spices. The problem with pepper farming in West Kalimantan is the lack of nutrient availability because plantation land is dominated by ultisol soils. Gamal leaf liquid organic diapers application is expected to increase the availability of nutrients in the growing media. The aim of the study was to determine the nutrient content of the liquid organic diapers of gamal leaves, to see the effect, as well as the best concentration and time of application on the vegetative growth of pepper plants. The study was carried out for four months, namely from January to April 2020 at the Pepper Plantation of Tengon Village, using a factorial compeletely randomized design pattern consisting of 2 factors, the concentration such as $10 \%, 20 \%, 30 \%, 40 \%$ control and liquid organic fertilizer application time (every time week and every two weeks). The results showed that liquid organic fertilizer of gamal leaves contained $12.7 \%$ C-organic., $0.27 \% \mathrm{~N}$-Total., $47.03 \mathrm{C} / \mathrm{N}$ ratio, $0,25 \% \mathrm{P}$., and 0,29 $\mathrm{K}$. The results of the research that giving Gamal leaf liquid organic fertilizer had a significant effect on shoot length, number of shoots and number of leaves of pepper plants, however, it did not significantly affect the time of emergence of pepper shoots. Liquid organic fertilizer concentration of $40 \%$ and time of application every week gave the best effect on shoot length $(25.33 \mathrm{~cm})$, number of shoots $(4.33$ shoots), and number of leaves (14.33 strands). It was concluded that the liquid organic diapers concentration treatment of gamal leaves had a significant effect on shoot length, number of shoots, and number of leaves of pepper plants but did not significantly affect the time of shoots emerging for pepper plants. The best poc concentration that increases pepper plant growth is $40 \%$ with every week application. It is recommended that further research can be carried out on the manufacture of liquid organic diapers of gamal leaves combined with animal waste on the growth of pepper plants, with application time of 2-3 times in one week.
\end{abstract}

Keywords: Gamal Leaf, liquid organic diapers, Pepper Plant, Application time

\section{Pendahuluan}

Lada merupakan komoditas rempah yang paling banyak diperdagangkan diantara rempah lainnya. Selain itu lada memiliki kegunaan sebagai bahan obat-obatan, bumbu masakan, pengawet, dan bahan pembuatan minyak wangi. Menurut Direktorat Jenderal Perkebunan (2014), produksi lada di Indonesia merupakan penyumbang devisa negara ke-6 setelah kelapa sawit, karet, kopi, kakao dan kelapa dengan produksi mencapai 4 ton/ha. Menurut Inaagrimap (2018), daerah sentra produksi lada di Indonesia terdapat pada Provinsi Bangka Belitung, Lampung, dan Kalimantan Barat. Kalimantan Barat memiliki luas lahan perkebunan lada sebesar 7.938 ha dengan produksi $809 \mathrm{~kg} / \mathrm{ha}$ yang masih tergolong rendah jika dibandingkan dengan provinsi Bangka Belitung yang mencapai $1,277 \mathrm{~kg} / \mathrm{ha}$.

Rendahnya produksi lada di Kalimantan Barat salah satunya disebabkan pertanian lada di 
Kalimantan Barat didominasi oleh tanah ultisol. Tanah ultisol merupakan tanah yang mempunyai kandungan hara yang rendah. Menurut Prasetyo \& Suryadikarta (2006), tanah ultisol merupakan tanah yang memiliki kandungan hara rendah karena mudah mengalami erosi, memiliki $\mathrm{pH}$ asam, kandungan bahan organik rendah serta memiliki kapasitas tukar kation (KTK) rendah. Oleh sebab itu, tanaman lada memerlukan unsur hara tambahan berupa pupuk untuk menunjang pertumbuhannya.

David (2016) menyatakan bahwa petani lada di Kalimantan Barat saat ini belum maksimal dalam usaha memperbaiki kesuburan tanah terutama penggunaan pupuk organik. Umumnya pupuk yang sering digunakan untuk pertumbuhan tanaman lada adalah pupuk anorganik, namun penggunaan pupuk anorganik secara terus menerus dapat menyebabkan kesuburan tanah menjadi menurun dan struktur tanah menjadi padat (mengeras). Menurut Isnaini (2006) dalam Purba et al. (2013) penggunaan pupuk anorganik secara terus menerus dapat mengurangi kadar organik dalam tanah, struktur tanah rusak, dan pencemaran lingkungan. Salah satu alternatif dalam mengurangi penggunaan pupuk anorganik untuk pertumbuhan tanaman lada adalah menggunakan pupuk organik.

Pupuk organik dapat diperoleh dari sisasisa tanaman seperti daun, buah, sisa hasil panen (jerami), dan kotoran hewan. Pupuk organik dapat diformulasikan dalam bentuk cair maupun padat (Nugroho, 2012). Kandungan pupuk organik cair dan waktu aplikasi dapat memengaruhi pertumbuhan tanaman. Hasil penelitian Sangadji (2018), pupuk organik cair NASA yang diberikan 3 kali pada umur 2, 4 dan 6 minggu setelah tanam (MST) berbeda nyata dengan perlakukan waktu aplikasi 1 dan 2 kali pada umur 2 dan 4 MST terhadap pertumbuhan jagung manis (Zea mays L.).

Salah satu sumber pupuk organik cair adalah daun gamal, karena daun gamal memiliki kandungan nutrisi yang diperlukan oleh tanaman. Menurut Oviyanti et al. (2016) daun gamal memiliki $0.24 \% \mathrm{~N}, 0.039 \%$ P-total, $8.38 \% \mathrm{~K}$, serta $12.4 \%$ C-Organik sehingga penggunaan pupuk POC daun gamal sangat baik bagi tanaman terutama dalam pertumbuhan vegetatif. Penggunaan POC daun gamal pada konsentrasi $120 \mathrm{ml} / \mathrm{liter}$ memberikan pengaruh yang signifikan terhadap rerata tinggi, jumlah daun dan lebar daun tanaman sawi (Brassica juncea Linn.). Penelitian Novriani (2016) juga menunjukkan bahwa pemberian POC daun gamal berpengaruh nyata terhadap tinggi tanaman, jumlah akar, umur berbunga, berat basah tanaman, berat basah bunga dan diameter bunga namun berpengaruh tidak nyata terhadap parameter jumlah daun, berat kering pucuk dan berat kering akar tanaman kubis bunga (Brassica oleracea L.). Hasil penelitian Khairunanissa et al. (2019) pemberian pupuk organik cair daun gamal yang difermentasi menggunakan Trichoderma harzianum memberikan pengaruh nyata terhadap tinggi tanaman, jumlah bunga dan berat buah namun tidak berbeda nyata terhadap jumlah daun tanaman terong ungu (Solanum melogena L.). Berdasarkan latar belakang diatas perlu dilakukan penelitian mengenai pertumbuhan tanaman lada terhadap pemberian pupuk orgnik cair daun gamal dengan waktu aplikasi berbeda.

\section{Bahan dan Metode}

\section{Waktu, Tempat, alat, dan bahan}

Penelitian ini dilaksanakan selama 4 bulan yaitu dari bulan Januari 2020 - April 2020 di perkebunan lada Desa Tengon, Dusun Kadik 1, Kabupaten Landak serta Analisis kandungan pupuk organik cair di Laboratorium Kimia dan Kesuburan Tanah Fakultas Pertanian Universitas Tanjungpura Pontianak.

Alat-alat yang digunakan dalam penelitian ini adalah alat tulis, ayakan tanah, cangkul, gelas ukur 100 dan 500 ml, ember, karung, kamera digital, saringan air, sprayer, $\mathrm{pH}$ meter, paranet, parang, penggaris, termometer, timbangan analitik, tali raffia dan polybag. Bahan-bahan yang digunakan dalam penelitian ini adalah daun gamal (Gliricidia sepium (Jacq) Kunth), stek tanaman lada (Piper nigrum Linn.), Effective Microorganism-4 (EM4), air, gula merah dan tanah ultisol.

\section{Rancangan Penelitian}

Penelitian ini menggunakan Rancangan Acak Lengkap (RAL) pola Faktorial yang terdiri atas 2 faktor. Faktor pertama yaitu konsentrasi pupuk organik cair (POC) yang terdiri dari 5 taraf perlakuan yaitu kontrol(A1), 10\%(A2), 20\%(A3), $30 \%(\mathrm{~A} 4)$, dan 40\%(A5). Faktor kedua yaitu 
waktu aplikasi POC yang terdiri dari 2 taraf yaitu setiap minggu (B1) dan setiap 2 minggu (B2). Masing-masing perlakuan dilakukan pengulangan sebanyak 3 (tiga) kali sehingga terdapat 30 unit percobaan.

\section{Pembuatan Pupuk Organik Cair Daun Gamal (Gliricidia sepium (Jacq) Kunth)}

Proses pembuatan pupuk organik cair daun gamal dilakukan dengan memasukan terlebih dahulu daun gamal yang telah dicincang dan ditimbang sebanyak $6,5 \mathrm{~kg}$ ke dalam ember berukuran 60 liter setelah itu dimasukan cairan EM4 sebanyak $140 \mathrm{ml}$, gula merah sebanyak 30,5 gram serta air bersih sebanyak 9,5 liter kemudian diaduk hingga homogen. Setelah itu campuran diinkubasi selama 14 hari, setiap hari pupuk organik cair daun gamal tersebut di aduk minimal 5-10 menit agar terjadi pertukaran udara karena suhu fermentasi harus dipertahankan antara $30-50^{\circ} \mathrm{C}$. Keberhasilan fermentasi dapat diketahui 14 hari setelah proses fermentasi dengan melihat perubahan warna daun gamal menjadi coklat kehitam-hitaman, selain itu terdapat aroma menyengat khas pupuk oganik cair.

\section{Analisis Kandungan Hara Pupuk Organik Cair}

Analisis kandungan hara pupuk organik cair dilakukan di Laboratorium Kimia dan Kesuburan Tanah Fakultas Pertanian, Universitas Tanjungpura Pontianak, adapun parameter yang dianalisis adalah kandungan unsur $\mathrm{N}, \mathrm{P}, \mathrm{K}, \mathrm{C}-$ Organik, Magnesium, kalsium dan $\mathrm{pH}$ pupuk organik cair.

\section{Persiapan Tanaman dan Media Tanam}

Tanaman yang digunakan pada penelitian ini berupa stek batang tanaman lada. Batang lada yang terdiri dari 5-7 buku, diambil dari tanaman lada yang telah berumur 9 bulan sampai 1,8 tahun (Hasibuan \& Tribowo, 2017). Tanah yang digunakan adalah tanah yang berasal dari lahan perkebunan lada yang merupakan tanah ultisol. Pengolahan media tanam dilakukan dengan cara tanah dihaluskan terlebih dahulu kemudian diayak untuk mengurangi serasah akar, batang maupun daun yang terdapat pada tanah. Tanah kemudian dimasukkan kedalam polybag berukuran 30x40 cm.

\section{Penanaman}

Penanaman dilakukan dengan cara, stek batang tanaman lada di tanam pada media tanam yang telah diberi lubang kurang lebih $15 \mathrm{~cm}$.

\section{Aplikasi Pupuk Organik Cair}

Aplikasi pupuk organik cair daun gamal dilakukan pada tanaman lada yang berumur 3 minggu setelah tanam. Aplikasi dilakukan dengan cara menyemprotkan pupuk organik cair daun gamal sebanyak $25 \mathrm{ml}$ sesuai konsentrasi perlakuan yang telah ditentukan ke organ daun dan batang tanaman lada. Pemupukan dilakukan pada waktu sore hari yaitu pukul 16.00-17.00 WIB.

\section{Pemeliharaan Tanaman}

Pemeliharaan tanaman meliputi penyiraman yang dilakukan dari awal penaman sampai dengan 11 minggu setelah tanam, menggunakan air bersih yang berasal dari air hujan sebanyak 2 kali sehari yaitu pada saat pagi hari pukul 07.00 - 08.00 WIB dan sore hari pukul $16.00-17.00$ WIB.

\section{Parameter Pengamatan}

Parameter yang diamati dalam penelitian ini adalah rerata waktu muncul tunas (hari), panjang tunas $(\mathrm{cm})$, jumlah tunas (tunas), dan jumlah daun (helaian).

\section{Pengukuran Faktor Lingkungan}

Pengukuran faktor lingkungan seperti $\mathrm{pH}$ tanah dilakukan sebelum melakukan perlakuan. Pengukuran suhu dilakukan setiap pengamatan.

\section{Analisis Data}

Data dianalisis menggunakan ANOVA (Analysis of Variance) di program SPSS versi 18,0. Hasil uji ANOVA yang berpengaruh nyata dilakukan uji lanjut menggunakan Duncan dengan taraf 5\% (Pramesti, 2011).

\section{Hasil dan Pembahasan}

\section{Analisis Kandungan Hara Pupuk Organik Cair Daun Gamal (Gliricidia sepium (Jacq) Kunth). \\ Berdasarkan analisis yang telah dilakukan kandungan hara POC daun gamal dapat dilihat pada Tabel 1 berikut.}


Tabel 1. Hasil Analisis Pupuk Organik Cair Daun Gamal (Gliricidia sepium (Jacq) Kunth.).

\begin{tabular}{lccc}
\hline & & \multicolumn{2}{c}{ Nilai } \\
\cline { 3 - 4 } Parameter & Snalisis & Satuan & $\begin{array}{c}\text { POC } \\
\text { Daun } \\
\text { Gamal } \\
\end{array}$ \\
& & 7,10 & SNI \\
\hline $\mathrm{pH}$ & - & 12,7 & Min 9,30 \\
C-organik & $(\%)$ & 0,27 & Min 0,40 \\
N-Total & $(\%)$ & 47,03 & $10-20$ \\
C/N Rasio & & 0,25 & Min 0,10 \\
Fosfor & $(\%)$ & 0,29 & Min 0,20 \\
Kalium & $(\%)$ & 0,05 & Maks \\
Kalsium & $(\%)$ & 0,04 & 25,50 \\
Magnesium & $(\%)$ & & Maks \\
& & & 0,60
\end{tabular}

Tabel 1 menunjukan bahwa pupuk organik cair (POC) daun gamal mengandung unsur hara C-Organik 12,7\%, N-Total $0,27 \%$ serta $\mathrm{C} / \mathrm{N}$ rasio 47,03 . Selain itu pupuk organik cair daun gamal juga mengandung unsur fosfor (P) sebanyak 0,25\% dan kalium (K) 0,29\% . Berdasarkan Standar Nasional Indonesia (SNI) tahun 2004, tentang spesifikasi kompos organik, pupuk organik cair memiliki minimal $9,30 \% \mathrm{C}$ Organik, 0,40\% N-Total, 0,10\% P, 0,20\% K, dan rasio $\mathrm{C} / \mathrm{N}$ 10-20 serta hara mikro kalsium maksimal $25,50 \%$, magnesium $0,60 \%$ dan $\mathrm{pH}$ minimal 6,80-7,49. Dari hasil analisis di atas pupuk organik cair daun gamal yang diperoleh secara keseluruhan memenuhi syarat hara minimal standar nasional Indonesia, namun mempunyai kandungan unsur nitrogen lebih rendah dibandingkan standar minimal.

\section{Waktu Muncul Tunas Tanaman Lada (hari)}

Hasil perlakuan pemberian konsentrasi dan waktu aplikasi POC daun gamal terhadap parameter waktu muncul tunas tanaman lada dapat lihat pada Tabel 2 berikut.

Tabel 2. Rerata Waktu Muncul Tunas (hari) Tanaman lada (Piper nigrum Linn.) terhadap Pemberian Pupuk Organik Cair Daun Gamal (Gliricidia sepium (Jacq) Kunth.)

Perlakuan Waktu Aplikasi (B) Rerata

\begin{tabular}{cccc}
\hline (Konsentrasi (A)) & $\begin{array}{c}\text { Setiap } \\
\text { Minggu } \\
\left(\mathrm{B}_{1}\right)\end{array}$ & $\begin{array}{c}\text { Setiap 2 } \\
\text { Minggu } \\
\left(\mathrm{B}_{2}\right)\end{array}$ & \\
\hline Kontrol $\left(\mathrm{A}_{1}\right)$ & 27,33 & 26,66 & $27,00^{\text {ns }}$ \\
$10 \%\left(\mathrm{~A}_{2}\right)$ & 21,33 & 26,66 & $24,00^{\text {ns }}$ \\
$20 \%\left(\mathrm{~A}_{3}\right)$ & 27,66 & 25,66 & $26,66^{\text {ns }}$ \\
$30 \%\left(\mathrm{~A}_{4}\right)$ & 26,00 & 26,33 & $26,16^{\text {ns }}$ \\
$40 \%\left(\mathrm{~A}_{5}\right)$ & 23,00 & 26,00 & $24,50^{\text {ns }}$ \\
\hline Rerata & $25,06^{\text {ns }}$ & $26,26^{\text {ns }}$ &
\end{tabular}

Keterangan: $\mathrm{A}, \mathrm{B}$, dan $\mathrm{A} * \mathrm{~B}$ tidak berpengaruh nyata berdasarkan ANOVA pada taraf 0,05

Hasil analisis statistik (ANOVA) pada Tabel 2 menunjukan bahwa perlakuan tunggal konsentrasi pupuk organik cair dan perlakuan tunggal waktu aplikasi pupuk organik cair serta perlakuan kombinasi antara konsentrasi dan waktu aplikasi pupuk organik cair tidak memberikan pengaruh yang nyata terhadap waktu muncul tunas tanaman lada.

\section{Panjang Tunas Tanaman Lada (cm)}

Hasil perlakuan pemberian konsentrasi dan waktu aplikasi POC daun gamal terhadap parameter tunas tanaman lada dapat dilihat pada Tabel 3 berikut.

Tabel 3. Rerata Panjang Tunas $(\mathrm{cm})$ Tanaman lada (Piper nigrum Linn.) setelah Pemberian Pupuk Organik Cair Daun Gamal (Gliricidia sepium (Jacq) Kunth)

\begin{tabular}{cccc} 
& \multicolumn{2}{c}{ Waktu Aplikasi (B) } & \\
\cline { 2 - 3 } $\begin{array}{c}\text { Perlakuan } \\
\text { (Konsentrasi(A)) }\end{array}$ & $\begin{array}{c}\text { Setiap } \\
\text { Minggu } \\
\left(\mathrm{B}_{1}\right)\end{array}$ & $\begin{array}{c}\text { Setiap 2 } \\
\text { Minggu } \\
\left(\mathrm{B}_{2}\right)\end{array}$ & \\
\hline Kontrol( $\left.\mathrm{A}_{1}\right)$ & 3,86 & 2,40 & $3,13^{\mathrm{A}}$ \\
$10 \%\left(\mathrm{~A}_{2}\right)$ & 10,56 & 5,73 & $8,15^{\mathrm{A}}$ \\
$20 \%\left(\mathrm{~A}_{3}\right)$ & 11,06 & 9,13 & $10,10^{\mathrm{AB}}$ \\
$30 \%\left(\mathrm{~A}_{4}\right)$ & 14,23 & 7,90 & $11,06^{\mathrm{AB}}$ \\
$40 \%\left(\mathrm{~A}_{5}\right)$ & 25,33 & 8,33 & $16,83^{\mathrm{B}}$ \\
\hline Rerata & $13,01^{\mathrm{A}}$ & $6,70^{\mathrm{A}}$ &
\end{tabular}

Keterangan: $\quad \mathrm{A}$ dan $\mathrm{B}$ berpengaruh, $\mathrm{A} * \mathrm{~B}$ tidak berpengaruh.

Angka yang diikuti dengan huruf besar yang sama pada kolom dan baris, tidak berbeda nyata berdasarkan uji Duncan pada taraf 0,05

Hasil analisis statistik pada Tabel 3 menunjukan bahwa perlakuan tunggal konsentrasi pupuk organik cair daun gamal dan perlakuan tunggal waktu aplikasi berpengaruh 
nyata terhadap panjang tunas tanaman lada, sedangkan perlakuan kombinasi konsentrasi pupuk organik cair daun gamal dan waktu aplikasi tidak berpengaruh nyata terhadap panjang tunas tanaman lada. Rerata panjang tunas pada perlakuan konsentrasi $40 \% \quad\left(\mathrm{~A}_{4}\right)$ berbeda nyata dengan perlakuan $\operatorname{kontrol}\left(\mathrm{A}_{0}\right)$ dan kosentrasi $10 \%\left(A_{1}\right)$, namun tidak berbeda nyata dengan perlakuan konsentrasi $20 \%\left(\mathrm{~A}_{2}\right)$ dan $30 \%$ $\left(\mathrm{A}_{3}\right)$. Rerata panjang tunas tertinggi ditunjukan pada perlakuan konsentrasi $40 \%\left(\mathrm{~A}_{4}\right)$ yaitu 16,83 $\mathrm{cm}$.

Hasil analisis data pada Tabel 3 juga menunjukan bahwa perlakuan waktu aplikasi pupuk organik cair daun gamal berpengaruh nyata terhadap panjang tunas tanaman lada namun tidak dapat dilakukan uji lanjut karena jumlah taraf perlakuan faktor B tidak memenuhi syarat uji lanjut. Namun yang memberikan rerata panjang tunas tertinggi adalah perlakuan POC yang diberikan setiap minggu yaitu $13,01 \mathrm{~cm}$.

\section{Jumlah Tunas (tunas)}

Hasil perlakuan pemberian konsentrasi dan waktu aplikasi POC daun gamal terhadap parameter jumlah tunas tanaman lada dapat dilihat pada Tabel 4 berikut.

Tabel 4. Rerata Jumlah Tunas Tanaman lada (Piper nigrum Linn.) terhadap Pemberian Pupuk Organik Cair Daun Gamal (Gliricidia sepium (Jacq) Kunth)

\begin{tabular}{lccc} 
& \multicolumn{2}{c}{ Waktu Aplikasi(B) } & \\
\cline { 2 - 3 } $\begin{array}{c}\text { Perlakuan } \\
\text { Konsentrasi (A)) }\end{array}$ & $\begin{array}{c}\text { Setiap } \\
\text { Minggu } \\
\left(\mathrm{B}_{1}\right)\end{array}$ & $\begin{array}{c}\text { Setiap } 2 \\
\text { Minggu } \\
\left(\mathrm{B}_{2}\right)\end{array}$ & Rerata \\
\hline Kontrol( $\left(\mathrm{A}_{1}\right)$ & 1,66 & 1,66 & 1,66 \\
$10 \%\left(\mathrm{~A}_{2}\right)$ & 3,33 & 2,66 & 2,66 \\
$20 \%\left(\mathrm{~A}_{3}\right)$ & 3,66 & 2,33 & 2,33 \\
$30 \%\left(\mathrm{~A}_{4}\right)$ & 4,00 & 4,66 & 4,66 \\
$40 \%\left(\mathrm{~A}_{5}\right)$ & 4,33 & 5,00 & 5,00 \\
\hline Rerata & $3,40^{\mathrm{A}}$ & $3,26^{\mathrm{A}}$ &
\end{tabular}

Keterangan: A berpengaruh nyata, $B$ dan $A * B$ tidak berpengaruh nyata.

Angka yang diikuti dengan huruf besar yang sama pada kolom dan baris, tidak berbeda nyata berdasarkan uji Duncan pada taraf 0,05

Hasil analisis statistik pada Tabel 4 menunjukan bahwa perlakuan tunggal konsentrasi pupuk organik cair daun gamal berpengaruh nyata terhadap jumlah tunas tanaman lada sedangkan perlakuan tunggal waktu aplikasi dan kombinasi antara konsentrasi dan waktu aplikasi tidak berpengaruh nyata terhadap jumlah tunas tanaman lada, terlihat bahwa rerata jumlah tunas pada perlakuan konsentrasi $40 \%\left(\mathrm{~A}_{4}\right)$ berbeda nyata dengan perlakuan kontrol $\left(\mathrm{A}_{0}\right)$, perlakuan konsentrasi $10 \%\left(\mathrm{~A}_{1}\right), 20 \%\left(\mathrm{~A}_{2}\right)$, namun tidak berbeda nyata dengan perlakuan konsentrasi $30 \%\left(\mathrm{~A}_{3}\right)$. Rerata jumlah tunas tanaman lada tertinggi terdapat pada perlakuan $40 \%\left(\mathrm{~A}_{4}\right)$ yaitu 4,66 tunas.

\section{Jumlah Daun (helaian)}

Hasil perlakuan konsentrasi dan waktu aplikasi POC daun gamal terhadap parameter jumlah daun tanaman lada dapat dilihat pada Tabel 5 berikut.

Tabel 5. Rerata Jumlah Daun (Helai) Tanaman lada (Piper nigrum Linn.) terhadap Pemberian Pupuk Organik Cair Daun Gamal (Gliricidia sepium (Jacq) Kunth.)

\begin{tabular}{cccc} 
& \multicolumn{2}{c}{ Waktu Aplikasi(B) } & \\
\cline { 2 - 3 } $\begin{array}{c}\text { Perlakuan } \\
\text { Konsentrasi }(\mathrm{A}))\end{array}$ & $\begin{array}{l}\text { Setiap } \\
\text { Minggu } \\
\left(\mathrm{B}_{1}\right)\end{array}$ & $\begin{array}{c}\text { Setiap } 2 \\
\text { Minggu } \\
\left(\mathrm{B}_{2}\right)\end{array}$ & Rerata \\
\hline Kontrol($\left(\mathrm{A}_{1}\right)$ & 3,00 & 2,00 & $2,50^{\mathrm{A}}$ \\
$10 \%\left(\mathrm{~A}_{2}\right)$ & 5,00 & 6,00 & $5,50^{\mathrm{ABC}}$ \\
$20 \%\left(\mathrm{~A}_{3}\right)$ & 6,33 & 3,00 & $4,66^{\mathrm{AB}}$ \\
$30 \%\left(\mathrm{~A}_{4}\right)$ & 9,00 & 9,00 & $9,00^{\mathrm{BC}}$ \\
$40 \%\left(\mathrm{~A}_{5}\right)$ & 14,33 & 6,33 & $10,33^{\mathrm{C}}$ \\
\hline Rerata & $7,53^{\mathrm{A}}$ & $5,26^{\mathrm{A}}$ &
\end{tabular}

Keterangan: A berpengaruh nyata, B dan $A * B$ tidak berpengaruh nyata.

Angka yang diikuti dengan huruf besar yang sama pada kolom dan baris, tidak berbeda nyata berdasarkan uji Duncan pada taraf 0,05 .

Hasil analisis statistik pada Tabel 5 menunjukkan bahwa perlakuan tunggal konsentrasi pupuk organik cair daun gamal berpengaruh nyata terhadap jumlah daun tanaman lada. Sedangkan perlakuan tunggal waktu aplikasi pupuk organik cair daun gamal dan kombinasi antara konsentrasi dan waktu aplikasi tidak berpengaruh nyata terhadap jumlah daun tanaman lada, terlihat bahwa perlakuan konsentrasi $40 \% \quad\left(\mathrm{~A}_{4}\right)$ berbeda nyata dengan perlakuan kontrol $\left(\mathrm{A}_{0}\right)$ dan $20 \%\left(\mathrm{~A}_{2}\right)$, namun tidak berbeda nyata dengan perlakuan $10 \%\left(\mathrm{~A}_{1}\right)$ dan dan $30 \%\left(\mathrm{~A}_{3}\right)$. Rerata jumlah daun tanaman 
lada tertinggi diperoleh pada perlakuan konsentrasi 40\% (A4) yaitu 10,33 helai.

\section{Analisis Kandungan Hara Pupuk Organik Cair Daun Gamal.}

Berdasarkan Tabel 1 terdapat kandungan $\mathrm{N}$ pada POC daun gamal sebesar $0,27 \%$. Hal ini sejalan dengan penelitian Oviyanti et al. (2016) yang mendapatkan kandungan $\mathrm{N}$ dalam daun gamal yang berasal dari daerah Palembang sebesar $0,24 \%$. POC daun gamal mengandung unsur nitrogen yang rendah jika dibandingkan dengan standar SNI yaitu 0,40 \%. Hal ini diduga karena daun gamal mengandung rasio $\mathrm{C} / \mathrm{N}$ tinggi yang menyebabkan aktivitas mikroorganisme dalam menguraikan (Pengomposan) bahan berjalan lambat, sehingga daun gamal tidak terurai dengan baik yang kemudian menyebabkan rendahnya kandungan hara POC tersebut. Menurut Nugroho (2012), masalah utama dalam proses pengomposan adalah terdapat pada rasio $\mathrm{C} / \mathrm{N}$ yang tinggi terutama pada bahan yang berasal dari tumbuhan, rasio $\mathrm{C} / \mathrm{N}$ yang efektif untuk proses pengomposan berkisar antara 30:1 hingga 40:1. Lambatnya proses dekomposisi bahan menyebabkan proses penguraian nitrogen kurang efektif sehingga menyebabkan POC daun gamal mengandung unsur nitrogen yang rendah. Rendahnya kandungan nitrogen menyebabkan rasio $\mathrm{C} / \mathrm{N}$ pada pupuk organik cair daun gamal lebih tinggi dari SNI yaitu 20. Hal ini sejalan dengan pernyataan Setyorini et al. (2006) bahan pupuk organik cair yang berasal dari daun-daunan memiliki kandungan nitrogen $0,4-1,0 \%$ serta rasio $\mathrm{C} / \mathrm{N}$ 40-80.

\section{Waktu Muncul Tunas}

Tabel 2 menunjukan bahwa parameter waktu muncul tunas tidak dipengaruhi oleh perlakuan yang diberikan yaitu POC daun gamal, perlakuan konsentrasi maupun waktu aplikasi. Hal ini diduga disebabkan daun gamal mengandung unsur hara nitrogen yang rendah sehingga tidak mampu memenuhi nutrisi yang dibutuhkan stek batang tanaman lada dalam menyusun hormon pertumbuhan seperti auksin dan sitokinin. Menurut Hanafiah (2012), nitrogen berperan penting bagi tanaman sebagai penyusun asam amino, klorofil dan hormon pertumbuhan seperti auksin dan sitokinin. Pertumbuhan tunas baru pada stek tanaman sangat dipengaruhi oleh tumbuhnya akar yang dibantu oleh hormon auksin eksogen pada POC daun gamal, sehingga tanaman lada dapat memproduksi hormon sitokinin, kemudian hormon tersebut diangkut menuju mata tunas untuk menstimulasi pertumbuhan tunas dengan meningkatkan pembelahan sel di primordia tunas. Hal ini diperkuat Nurbaiti \& Muazzinah (2017) yang menyatakan bahwa auksin berperan dalam proses pemanjangan sel dan inisiasi pertumbuhan akar tanaman serta hormon sitokinin yang berperan dalam pembentukan enzim untuk membantu merangsang pembelahan sel dalam jaringan dan pertumbuhan tunas tanaman.

\section{Panjang Tunas}

Rerata panjang tunas tertinggi diperoleh dari perlakuan konsentrasi $\mathrm{A}_{4}(40 \%)$ (Tabel 3). Konsentrasi POC daun gamal $40 \%$ mampu memicu pertumbuhan panjang tunas tanaman lada. Hal ini diduga dalam POC daun gamal konsentrasi $40 \%$ mengandung unsur hara $\mathrm{N}$ dan unsur hara lainnya yang mampu berperan dalam proses pemanjangan sel. Hal ini sejalan dengan pernyataan Rahmah et al. (2014) penambahan panjang tunas tanaman terjadi karena nitrogen mampu mengaktifkan hormon pertumbuhan pada meristem apikal sehingga terjadi penambahan panjang tunas. Selain itu penambahan panjang tunas tanaman juga dipengaruhi oleh unsur fosfor yang mampu membantu tanaman dalam menambahan jumlah sel baru pada jaringan sehingga dengan bertambahnya jumlah dan panjang sel dapat memengaruhi panjang tunas tanaman lada. Rahmawati et al. (2018) menyatakan bahwa penambahan panjang tunas tanaman dipengaruhi unsur hara fosfor yang dapat membentuk sel baru pada jaringan yang sedang tumbuh.

Selain itu unsur fosfor dan kalium juga sangat berperan dalam proses fotosintesis, respirasi, pemanjangan dan perbesaran sel tanaman serta berperan dalam proses pertumbuhan akar tanaman. Unsur kalium juga berperan dalam proses membuka dan menutupnya stomata untuk menyerap nutrisi dari pupuk organik cair yang disemprotkan pada permukaan bawa daun tanaman lada. Menurut Rochayati et al.dalam Meylia et al. (2018) fosfor merupakan unsur hara yang berperan dalam proses fotosintesis, respirasi, penyimpanan energi, pembelahan sel serta berperan dalam 
proses pertumbuhan akar tanaman. Meylia et al. (2018), juga menyatakan bahwa kombinasi antara pupuk fosfor dan kalium berpengaruh nyata terhadap tinggi tanaman, jumlah bunga per tandan, jumlah buah per tandan, jumlah buah panen pertanaman, bobot per buah, dan bobot buah tanaman tomat.

\section{Jumlah Tunas}

Hasil penelitian pada Tabel 3 menunjukan bahwa perlakuan konsentrasi POC daun gamal memberikan pengaruh nyata terhadap jumlah tunas tanaman lada. Hal ini disebabkan karena daun gamal memiliki unsur hara N, P, K dan hara mikro yang dapat menyediakan nutrisi yang cukup bagi pertumbuhan tunas tanaman lada. Penambahan jumlah tunas tanaman lada berhubungan dengan ketersediaan hara yang terdapat pada pupuk organik cair daun gamal, unsur nitrogen pada POC daun gamal yang digunakan tergolong rendah sehingga diperlukan konsentrasi yang cukup tinggi dan waktu aplikasi yang tepat untuk dapat memenuhi unsur hara yang dibutuhkan tanaman lada. Faini \& Moko (2006) menyatakan bahwa pemberian pupuk nitrogen dapat meningkatkan pertumbuhan tunas tanaman merawan (Hopea odorata Roxb.). Hal ini berhubungan dengan nitrogen yang berperan menyediakan enzim-enzim yang dibutuhkan tanaman pada saat melakukan pembelahan sel sehingga menyebabkan proses pertumbuhan tunas-tunas baru pada tanaman lada. Tripama \& Pangesti (2015) menyatakan bahwa unsur nitrogen mampu menyediakan protein yang dibutuhkan tanaman pada saat pembelahan sel, sehingga pembelahan sel pada organ tanaman lebih efisien. Selain itu, fosfor juga berperan penting dalam reaksi enzim yang membantu dalam proses pembelahan sel dan jaringan meristem tanaman.

\section{Jumlah daun}

Hasil penelitian menujukan bahwa perlakuan konsentrasi POC daun gamal memberikan pengaruh nyata terhadap jumlah daun tanaman lada. Perlakuan terbaik terlihat pada perlakuan konsentrasi $40 \%\left(\mathrm{~A}_{4}\right)$ dengan rerata jumlah daun 10,33 helai. Hal ini menunjukan bahwa kandungan hara yang terdapat dalam POC daun gamal mampu memenuhi nutrisi yang dibutuhkan tanaman lada untuk membantu mengaktifkan enzim yang digunakan dalam proses pembelahan sel sehingga menyebabkan pembentukan daun tanaman menjadi lebih cepat. Hal ini sejalan dengan pernyataan Dhani et al. (2013), pembentukan daun tanaman sangat dipengaruhi oleh ketersedian unsur hara nitrogen dan fosfor pada medium yang tersedia bagi tanaman, kedua unsur ini berperan dalam pembentukan sel-sel baru dan komponen utama penyusun senyawa organik dalam tanaman seperti asam amino, asam nukleat, klorofil, ADP dan ATP.

Pertumbuhan daun merupakan bagian dari pertumbuhan vegetatif tanaman. Penambahan jumlah daun berhubungan dengan penambahan panjang dan jumlah tunas pada tanaman, karena penambahan panjang dan jumlah tunas akan diikuti oleh penambahan nodus-nodus pada batang yang merupakan tempat melekatnya daun tanaman. Hal ini menunjukan bahwa unsur hara yang terdapat pada POC duan gamal dapat dimanfaatkan secara efisien oleh tanaman lada sehingga dapat meningkatkan pertumbuhannya. Menurut Hakim et al. (1986) unsur N berfungsi dalam pembentukan sel-sel klorofil dimana klorofil berguna dalam proses fotosintesis sehingga dibentuk energi yang diperlukan sel untuk aktifitas pembelahan, pembesaran dan pemanjangan. Selanjutnya Lakitan (2000) menyatakan bahwa secara fisiologis fosfor $(\mathrm{P})$ berperan dalam reaksi-reaksi pada fase gelap, fotosintesis, respirasi, dan merupakan bagian dari nukleotida.

Panjang tunas, jumlah tunas, dan jumlah daun tanaman lada dipengaruhi oleh konsentrasi POC daun gamal yang di semprotkan pada daun tanaman lada. Penyerapan hara melalui daun umumnya diserap melalui stomata sehingga kandungan unsur hara yang terdapat dalam pupuk organik cair daun gamal berperan penting dalam proses terbuka dan tertutupnya stomata terutama unsur kalium. Hal ini dinyatakan oleh Fadila (2018), pemberian pupuk organik cair (Bio 88) yang disemprotkan langsung pada daun tanaman lada dapat meningkatkan pertumbuhan tanaman lada, karena pupuk organik cair dapat langsung diserap oleh tanaman melalui stomata pada daun dan POC tidak merusak daun tanaman lada. Sehingga dalam jumlah yang sedikit dan waktu aplikasi yang tepat dapat memenuhi unsur hara yang dibutuhkan untuk pertumbuhan tanaman lada. Selain itu Pertiwi (2011) dalam Rajak et al. (2016) menyatakan bahwa 
pemupukan melalui daun perlu dilakukan secara berulang-ulang karena serapan hara oleh daun terbatas jika dibandingkan melalui akar. Pupuk organik cair daun gamal yang disemprotkan pada daun tanaman dapat menguap jika terkena sinar matahari yang berlebihan.

Hasil analisis menunjukkan bahwa pengaruh interaksi antara POC daun gamal dan waktu aplikasi POC tidak berbeda nyata terhadap semua parameter. Keadaan ini menunjukkan bahwa faktor konsentrasi POC dengan waktu aplikasi POC tidak secara bersamaan dalam memengaruhi pertumbuhan stek batang tanaman lada, karena kedua faktor tersebut sama-sama mendukung pertumbuhan tanaman tapi tidak menukung jika salah satu faktor menutupi faktor lainnya. Hasil penelitian ini sejalan dengan pernyataan Astuti et al. (2014), faktor interaksi perlakuan konsentrasi dan jenis POC tidak berpengaruh nyata disebabkan karena masingmasing faktor tidak terdapat hubungan yang saling mempengaruhi sehingga perlakuan berpengaruh secara terpisah terhadp pertumbuhan tanaman sawi.

\section{Kesimpulan}

Berdasarkan hasil penelitian yang telah dilakukan, disimpulkan bahwa pupuk organik cair daun gamal mengandung unsur hara COrganik $12,7 \%$, N-Total $0,27 \%$ serta $\mathrm{C} / \mathrm{N}$ rasio 47,03. Selain itu pupuk organik cair daun gamal juga mengandung unsur fosfor (P) sebanyak $0,25 \%$ dan kalium (K) 0,29\%. Selain itu, perlakuan konsentrasi pupuk organik cair daun gamal memberikan pengaruh nyata terhadap panjang tunas, jumlah tunas dan jumlah duan tanaman lada namun tidak berpengaruh nyata terhadap waktu muncul tunas tanaman lada serta konsentrasi terbaik pupuk organik cair daun gamal yang meningkatkan pertumbuhan tanaman lada adalah $40 \%$, dengan waktu aplikasi setiap minggu.

\section{Ucapan terima kasih}

Penulis mengucapkan terima kasih kepada Dr.Zulfa Zakiah, S.Si, M.Si. dan Riza Linda, S.Si, M.Si atas bimbingan dan saran yang diberikan serta kepada semua pihak yang turut mendukung selama penulisan artikel ini dimulai hingga selesai.

\section{References}

Astuti, P., Manullang, G.S. \& Rahmi, A. (2014). "Pengaruh Jenis dan Konsentrasi Pupuk Organik Cair terhadap Pertumbuhan dan Hasil Tanaman Sawi (Brassica juncea L.) Varietas Tosakan”. Jurnal Agrifor. 13 (1): 33-40.

Direktorat Jenderal Perkebunan (2014). Neraca Perkebunan Tri Wulan IV 2013. Diakses 25 April 2019, 00.00 WIB. DOI: http://ditjenbun.pertanian.go.id.

David, J. (2017). Percepatan Pengembangan Lada Sebagai Komoditas Strategis Di Kalimantan Barat, Balai Pengkajian Teknologi Pertanian, Kalimantan Barat. 7 (2): 1045-1052

Dhani, H., Wardati. \& Rosmimi. (2013). Pengaruh Pupuk Vermikompos Pada Tanah Inceptisol Terhadap Pertumbuhan dan Hasil Sawi Hijau (Brassica juncea L.). Riau. Universitas Riau. Jurnal Sains dan Teknologi 18 (2). ISSN: 1412:2391.

Fadila, R. (2018). Aplikasi Kompos Trichoderma sp. Dan Pupuk Organik Cair Pada Pertumbuhan Dan Produksi Tanaman Lada Perdu (Piper nigrum L.). Skripsi. Fakultas Pertanian Universitas Hasanuddin Makassar.

Faini, A. \& Moko, H. (2006). Pengaruh Pupuk Nitrogen terhadap Produksi Tunas dan Kualitas Stek Pucuk Merawan. Jurnal Penelitian Hutan Tanaman. Pusat Litbang Hutan Tanaman. 3 (1): 45-52.

Hanafiah, K.A. (2005). Dasar-Dasar Ilmu Tanah. PT. Raja Grafindo Persada, Jakarta.

Hakim, N., Nyakpa, M.Y., Lubis, A.M., Pulung, M.A., Munawar, A. \& Go, B.H. (1986). Kesuburan Tanah. Penerbit Universitas Lampung.

Inaagrimap. (2018). Sentra Produksi Lada. doi: ,https://inaagrimap.litbang.pertanian.go.id /index.php/sentra-produksi/tanaman- 
perkebunan/lada. diakses pada tanggal 06/06/2021 pukul 14.19 WIBA.

Khairunanissa. Rizali, A., \& Khamidah, N. (2019). Aplikasi Pupuk Organik Cair Daun Gamal Menggunakan Trichorderma harzianum terhadap Pertumbuhan dan Hasil Terong Ungu. Jurnal Tugas Akhir Mahasiswa. 2(3):24-29.

Lakitan, B. (2000). Dasar-Dasar Fisiologi Tumbuhan. Raja Grafindo perkasa. Jakarta

Meylia, R.D., \& Koesriharti. (2018). Pengaruh Pemberian Pupuk Fosfor dan Sumber Kalium Yang Berbeda terhadap Pertumbuhan dan Hasil Tanaman Tomat.

Nugroho, P. (2012). Panduan Pembuatan Pupuk Kompos Cair. Penerbit Pustaka Baru Press. Yogyakarta.

Nurbaiti \& Muazzinah, S.U. (2017). Pemberian Air Kelapa sebagai Zat Pengatur Tumbuh Alami pada Stum Mata Tidur beberapa Klon Tanaman Karet (Hevea brasiliensis Muell Arg.). Jurnal Online Mahasiswa FAPERTA. Universitas Riau. 4 (5): 3-6.

Novriani. (2016). Pemanfaatan Daun Gamal sebagai Pupuk Organik Cair (Poc) untuk Meningkatkan Pertumbuhan dan Produksi Tanaman Kubis Bunga (Brassica Oleracea L.) pada Tanah Podsolik. Jurnal Klorofil $X I-1$. Dosen Universitas Baturaja, Sumatera Selatan. 11 (1): 15-19

Oviyanti, F., Syarifah. \& Hidayah, N. (2016). Pengaruh Pemberian Pupuk Organik Cair Daun Gamal (Gliricidia sepium (Jacq.) Kunth ex Walp.) terhadap Pertumbuhan Tanaman Sawi (Brassica juncea L.). Jurnal Biota. 2 (1): 63-65.

Prasetyo, B.H. \& Suriadikarta, D.A. (2006) Karakteristik, Potensi, dan Teknologi Pengolahan Tanah Ultisol untuk Pengembangan Pertanian Lahan Kering di Indonesia. Jurnal Litbang Pertanian. 25 (2): $39-44$
Pramesti, G. (2011). SPSS 18.0. dalam Rancangan Percobaan. PT. Alex Media Komputindo. Jakarta.

Purba, E., Lahay, R.R. \& Simanjuntak, A. (2013). Respon Pertumbuhan dan Produksi Bawang Merah (Allium ascalonicum L.) terhadap Pemberian Pupuk NPK dan Kompos Kulit Buah Kopi. Jurnal Online Agroekoteknologi. 1 (3): 362-372.

Rajak, A. Patty, J.R. \& Nendissa, J.I. (2016). Pengaruh Dosis dan Interval Waktu Pemberian Pupuk Organik Cair Bmw terhadap Pertumbuhan Dan Produksi Tanaman Sawi (Brassica juncea L.). Jurnal Budidaya Pertanian. 12 (2): 66-73.

Rahmawati, I.D., Purwani, K.I., \& Muhibuddin, A. (2018). Pengaruh Konsentrasi Pupuk P terhadap Tinggi dan Panjang Akar Tagetes erecta L. (Marigold) Terinfeksi Mikoriza yang Ditanam secara Hidroponik. Jurnal Sains dan Seni ITS. 7 (2): 43-45.

Rahmah, A., Izzati, M., \& Parman, S. (2014), Pengaruh Pupuk Organik Cair Berbahan Dasar Limbah Sawi Putih (Brassica Chinensis L.) terhadap Pertumbuhan Jagung Manis (Zea Mays L. Var. Saccharata). Jurnal Buletin Anatomi Dan Fisiologi. Universitas Diponogoro. 22 (1): 65-71.

Sangadji, Z. (2018). Pengaruh Konsentrasi Dan Waktu Aplikasi Pupuk Organik Cair Nasa Terhadap Pertumbuhan Dan Produksi Tanaman Jagung Manis Pada Tanah Sawah. Jurnal Median .10 (1): 18-27.

Setyorini, D., Saraswati, R., Anwar, \& Ea, K. (2006). Kompos, dalam Pupuk Organik dan Hayati. BBSDLP-Badan Litbang Pertanian. pp: 11-40.

Tripama, B. \& Pangesti, P.D. (2015). Aplikasi Pemupukan Nitrogen dan Molybdenum terhadap Pertumbuhan dan Produksi Tanaman Buncis Blue Lake (Phaseulus Vulgaris) di Tanah Entisol. Agritrop Jurnal Ilmu-Ilmu Pertanian. 11 (2): 11-26. 